\title{
Е.Ф. Троицкий
}

\section{ЛИССАБОНСКИЙ ДОГОВОР И РЕГИОНАЛЬНОЕ ИЗМЕРЕНИЕ ЕВРОПЕЙСКОГО СОЮЗА}

\author{
Статья подготовлена в рамках гранта имени Жана Монне № 561105-EPP-1-2015-1-RU-EPPJMO-CHAIR
} «Европейский регионализм и политика сплочения ЕС».

\begin{abstract}
Анализируются изменения, внесенные Лиссабонским договором в политику сплочения ЕС и систему взаимодействия регионов с институтами ЕС. Рассматриваются понятие «территориальное сплочение» и опыт реализации политики в этой сфере, новая трактовка принципа субсидиарности, повышение статуса Комитета регионов и запуск «системы раннего предупреждения», позволяющей парламентам стран ЕС участвовать в европейском законодательном процессе. Анализируются условия, ограничивающие действенность внесенных Договором новаций, подчеркивается их ориентированность на долгосрочную перспективу.

Ключевые слова: Лиссабонский договор; территориальное сплочение; субсидиарность; система раннего предупреждения.
\end{abstract}

С каждой новой реформой Европейского Союза, воплощаемой в заключении нового основополагающего договора, в ЕС вспыхивает дискуссия о соотношении наднационального (представленного, прежде всего, Еврокомиссией и Европарламентом) и субнационального (представленного регионами и местными органами власти) уровней европейского строительства. Усилиями сообщества специалистов по экономическим, социальным, правовым, культурноисторическим, теоретико-методологическим аспектам европейской интеграции вокруг проблематики регионального измерения функционирования ЕС сформировалось обширное и постоянно прирастающее поле научной литературы. Среди основных исследовательских позиций - концепция «Европы регионов», которая, предположительно, вызревает в недрах «Европы государств» $[1,2]$; различные версии теории «многоуровневого управления», утверждающей, что регионы, как и другие негосударственные акторы, играют в процессе принятия решений в ЕС все более заметную и самостоятельную роль [3, 4]; концепция «региональной слепоты» ЕС, которую невозможно «исцелить» принимаемыми паллиативными мерами [5]. Свой вклад в эту дискуссию внесли и отечественные европеисты, склонные делать акцент на усилении роли регионов в европейском интеграционном процессе [6. С. 251-266; 7. С. 251-266]. Актуальность соответствующей проблематики усиливается как в связи с ростом автономистских (северные регионы Италии) и сепаратистских (Каталония, Шотландия) устремлений со стороны целого ряда регионов ЕС, так и в свете волны евроскептических настроений, нахлынувшей на ЕС в 2015-2016 гг.

Лиссабонский договор, вступивший в силу 1 декабря 2009 г., внес в право ЕС ряд новых положений, призванных усилить региональное измерение деятельности Евросоюза. В настоящей статье анализируются как эти новации, так и сложившаяся за шесть лет действия Договора практика их применения. Вклад статьи в обсуждение рассматриваемой проблематики видится в ком- плексном характере анализа изменений, внесенных Лиссабонским договором в функционирование связки «ЕС - регионы», и в попытке соотнесения «буквы» договора с политическими реалиями.

Прежде всего в Лиссабонском договоре нашел отражение новый подход к политике сплочения ЕС. Было расширено само понятие «сплочения»: если в Договоре, учреждающем Европейское сообщество, речь шла об «экономическом и социальном сплочении» [8. P. 103-105], то в Лиссабонском договоре говорится об «экономическом, социальном и территориальном сплочении» [9. Р. 127-128]. Таким образом, территориальное измерение сплочения стало, наряду с экономическим и социальным компонентом, признаваться одной из основных политических целей ЕС. Были более точно определены категории регионов, нуждающихся в поддержке: ст. 174 Договора о функционировании ЕС установила, что «среди соответствующих регионов особое внимание уделяется сельским районам, местностям, где происходят индустриальные преобразования, и регионам, которые страдают от серьезных и постоянных препятствий своему развитию, обусловленных природными или демографическими факторами, таким как регионы крайнего севера с очень низкой плотностью населения, островные, трансграничные и горные регионы» [Ibid. P. 127]. В Договоре, учреждающем Европейское сообщество, напрямую упоминались лишь «регионы или острова, находящиеся в наименее благоприятных условиях, включая сельские районы» [8. Р. 103].

Однако формулировка «территориальное сплочение» нуждается в конкретизации, которой не содержится в Договоре. В Пятом отчете Еврокомиссии об экономическом, социальном и территориальном сплочении, опубликованном в июне 2008 г., подчеркивается, что «территориальное сплочение усиливает важность доступа к услугам, устойчивого развития, функциональной географии и территориального анализа» [10. Р. 24]. Речь идет о доступе к службам общего эко- 
номического значения (образованию, здравоохранению, торговым, финансовым услугам), территориальных аспектах природоохранной политики, использовании при проведении экономической политики подходов, более гибких и функциональных с географической точки зрения (например, выделении макрорегионов, крупных городских регионов, объединении, при необходимости, сельских районов и небольших городов), углубленном исследовании воздействия, оказываемого различными направлениями деятельности ЕС на конкретные территории.

В декабре 2008 г. Еврокомиссия опубликовала «Зеленую книгу о территориальном сплочении», в которой говорилось, что главный смысл нового понятия - конвертация территориального разнообразия ЕС в экономический актив, сохранение «особого, европейского образа жизни, при котором ценится устойчивое развитие, защита природных ресурсов и культурные традиции», «поощрение сотрудничества, взаимодействия и связей между малыми и крупными городами и окружающими их сельскими районами» [11. Р. 4]. В «Зеленой книге» подчеркивалось, что «европейские граждане не должны находиться в ущемленном положении в плане возможностей трудоустройства, жилищных условий, доступа к общественным службам» только изза того, что живут в том или ином регионе [Ibid.].

В мае 2011 г. на неформальной встрече министров стран ЕС, ответственных за пространственное планирование и территориальное развитие, был принят документ, получивший название «Территориальная повестка дня Европейского Союза 2020», в котором территориальное сплочение определялось как «система принципов гармоничного, сбалансированного, эффективного, устойчивого территориального развития» [12. P. 3]. Подчеркивалось, что «территориальное сплочение предоставляет равные возможности гражданам и предприятиям, где бы они ни находились, для максимального использования своего территориального потенциала» и «содействует конвергенции между экономикой благополучных территорий и экономикой территорий, отстающих в развитии» [Ibid.]. Был выделен ряд приоритетов политики в сфере территориального сплочения: содействие полицентричному развитию территории ЕС; интегрированное развитие городов, сельских районов и районов с особыми географическими условиями; интеграция трансграничных регионов в единые функциональные пространства; обеспечение «глобальной конкурентоспособности регионов, опирающейся на сильную местную экономику»; улучшение территориальной доступности через развитие транспорта, энергосетей, широкополосного интернета; обеспечение связи между «экологическими, ландшафтными и культурными ценностями регионов» [Ibid. Р. 6-8]. Нетрудно заметить, что сформулированные цели носят весьма расплывчатый и во многом декларативный характер и не подкреплены конкретными пока- зателями, позволяющими оценить, насколько успешно идет их реализация.

В июле 2015 г. по заказу правительства председательствовавшего в EC Люксембурга компанией «Спейшл Форсайт», занимающейся исследованиями в сфере европейского территориального развития, был проведен анализ деятельности ЕС в сфере территориального сплочения. Оценки экспертов не только не позволяют констатировать прогресс, но и свидетельствуют о частичной утрате достижений прошлых лет. Так, рост населения концентрируется в регионах Западной Европы, в то время как Восточная Германия, страны Балтии, Болгария, Румыния, Восточная Венгрия теряют население. Экономический кризис, начавшийся в 2008 г., привел к возрастанию разрыва в ВВП на душу населения между самыми богатыми и самыми бедными регионами, который в 2000-2008 гг. сокращался. Усугубился разрыв в уровнях занятости: в 2013 г. соответствующие диспропорции были выше, чем в 2000 г., причем особенно пострадали Греция, Испания, Португалия, Южная Италия [13. Р. 9-16].

Эксперты отметили, что, по-видимому под влиянием поразивших Евросоюз кризисов, «пространственное планирование и долгосрочные стратегии» утрачивают «политическую популярность во многих странахчленах и на европейском уровне» [Ibid. P. 44]. Подчеркивалось, что политикам и функционерам, в особенности на национальном, региональном и локальном уровнях, недостает знаний о территориальном сплочении, а множественность и расплывчатость определений этого понятия создает трудности в коммуникации и становится препятствием для его трансляции в плоскость реальной политики. Показательно, что представленный в 2015 г. новым составом Европейской Комиссии амбициозный план стимулирования экономического развития («план Юнкера») не содержит даже упоминаний о «территориальном сплочении».

Важной новацией Лиссабонского договора в сфере политики сплочения стало расширение полномочий Европейского Парламента: если ранее Парламент лишь давал согласие на принятие регламентов Структурных Фондов и Фонда сплочения, являющихся основными инструментами финансовой поддержки регионов и беднейших стран Евросоюза, то со вступлением в силу Договора на принятие этих актов была распространена обычная законодательная процедура [9. Р. 128]. Соответственно, в Совете при утверждении регламентов Фондов действует принцип квалифицированного большинства, тогда как до 2007 г. эти решения требовали единогласия. Расширение полномочий Парламента (и, следовательно, повышение роли его Комитета по региональному развитию) усилило возможности регионов оказывать неформальное влияние на формирование политики сплочения, поскольку немалое число евродепутатов имеет тесные связи на региональном уровне. 
Лиссабонский договор ввел ряд положений, открывающих для регионов дополнительные возможности участия в принятии решений на уровне ЕC и защиты своих интересов. Принцип субсидиарности был впервые распространен на региональный и местный уровни власти: статья 5 Договора о Европейском Союзе установила, что «согласно принципу субсидиарности, в сферах, которые не относятся к его исключительной компетенции, Союз действует лишь тогда и в такой степени, в какой цели предполагаемого действия не могут достаточным образом быть достигнуты государствами-членами на центральном, региональном или местном уровне, но, ввиду масштабов или последствий предполагаемого действия, могут быть лучше достигнуты на уровне Союза» [9. Р. 18]. Договор зафиксировал принцип региональной и местной автономии: статья 4.2 провозглашает, что Союз «уважает национальные идентичности государств-членов, воплощенные в их основополагающих политических и конституционных структурах, в том числе в области регионального и местного самоуправления» [Ibid.].

Лиссабонский договор усилил роль национальных парламентов в законодательном процессе ЕС. Они получили право следить за соблюдением принципа субсидиарности через введенную Договором «систему раннего предупреждения» [Ibid. Р. 207-208]. Согласно этой системе, парламенты стран ЕС должны получать законопроекты одновременно с Европейским Парламентом и Советом ЕС, причем непосредственно от институтов ЕС, а не, как прежде, от правительств своих стран. Затем в течение восьми недель парламенты могут направить председателям Еврокомиссии, Европарламента и Совета мотивированные заключения о соответствии законопроекта принципу субсидиарности. Каждый национальный парламент имеет два голоса; в случае двухпалатного парламента, каждой палате предоставляется один голос. Если не менее трети голосов национальных парламентов подано против законопроекта как нарушающего принцип субсидиарности, он подлежит пересмотру (этот порог снижается до четверти, если речь идет о сферах судебного сотрудничества по уголовным делам и полицейского сотрудничества). Процедура пересмотра, впрочем, не означает, что инициатор законопроекта обязан внести в него изменения; возможен и вариант, при котором законопроект все равно выносится на расссмоттрение Европарламента и Совета.

В странах, где верхние палаты парламентов представляют субъекты федерации или административнотерриториальные единицы, «система раннего предупреждения» открывает регионам прямую возможность влиять на законодательный процесс в ЕС. В настоящее время верхние палаты парламентов Австрии, Бельгии, Германии и, после реформы 2015 г., Италии представляют непосредственно региональные интересы. Кроме того, Протокол о применении принципов пропорциональности и субсидиарности, являющийся приложени- ем к Лиссабонскому договору, предусматривает, что национальные парламенты могут консультироваться с «региональными парламентами с законодательными полномочиями» [Ibid. P. 207; 14].

За время действия Лиссабонского договора «система раннего предупреждения» сработала дважды. В первом случае (предложение Еврокомиссии, затрагивающее право на забастовки) 19 из 54 голосов, предоставленных национальным парламентам, было подано за признание законопроекта нарушающим принцип субсидиарности; проект был отозван Еврокомиссией. Во втором случае (предложение Еврокомиссии об учреждении Европейского офиса общественного прокурора) был собран необходимый минимум протестных голосов - 18, но Еврокомиссия не сняла проект и добилась его одобрения Европарламентом; процедура утверждения в Совете продолжается [15. Р. 3].

Наконец, Лиссабонский договор расширил полномочия Комитета регионов ЕС. Комитет впервые получил право обращаться в Суд ЕС - как для защиты собственных институциональных прерогатив, так и для оспаривания законодательных актов, которые, по его мнению, нарушают принцип субсидиарности [9. Р. 162]. Срок полномочий Комитета регионов продлен с четырех до пяти лет, а его председателя - с двух до двух с половиной. Таким образом, деятельность Комитета синхронизируется с деятельностью Комиссии и Парламента, что также должно способствовать повышению его роли.

Однако эффективность использования Комитетом регионов права обращаться в Суд и возможности оперировать угрозой судебного иска в переговорах с другими структурами ЕС ограничиваются разнородностью его состава: как известно, в Комитет входят представители и региональных властей (причем регионов как «сильных», имеющих конституционный статус, так и «слабых», являющихся чисто административными конструкциями), и органов местного самоуправления. Кроме того, реальное значение этой новации будет определяться тем, как Суд ЕС будет интерпретировать принцип субсидиарности. За первые шесть лет действия Лиссабонского договора Комитет ни разу не воспользовался этим правом.

Действенность «системы раннего предупреждения» как инструмента вовлечения регионов в законодательный процесс ограничивается тем обстоятельством, что палаты парламентов, представляющие регионы, оказываются в ЕС в абсолютном меньшинстве, а большинство принадлежит парламентам унитарных государств. К тому же национальные парламенты не вправе оспаривать предполагаемые нарушения принципа пропорциональности, устанавливающего, что «содержание и форма действий Союза не должны превышать рамки того, что необходимо для достижения целей Договоров» [Ibid. P. 18], - парламентские прерогативы касаются только сферы субсидиарности. Решающее слово, как показывает проект создания 
Европейского офиса общественного прокурора, остается за институтами ЕС.

Безусловно, новации, внесенные Лиссабонским договором в сферу участия регионов в политике ЕС, оказываются довольно скромными при их сопоставлении с теми проектами, которые при подготовке Договора выдвигались Комитетом регионов и «сильными» регионами. Так, Комитет регионов настаивал на праве вето на законопроекты в сферах, в которых обязательно его участие в процедуре консультации, и возможности обращаться в Суд ЕС для проверки правомочности актов EC (т.е. такого же права доступа к Суду, как Еврокомиссия, Европарламент, Совет и страны-члены) [16]. Группа «Реглег», объединяющая регионы, наделенные собственной законодательной властью, требовала закрепления за «конституционными» регионами особого статуса в Договорах ЕС и в рамках Комитета регионов [17. Р. 290]. Немецкие земли, опасаясь за свои прерогативы, выдвигали проигнорированное Лиссабонским договором требование ограничить применение в ЕС процедуры, позволяющей Совету министров единогласно принимать решения о переходе к принятию решений в отдельных сферах квалифицированным большинством голосов [Ibid. P. 289].

Однако вряд ли можно считать рассмотренные нововведения малозначительными. В долгосрочном плане они могут способствовать усилению регионального измерения политического пространства Евросоюза повышению роли Комитета регионов, интенсификации взаимодействия между национальными парламентами и институтами ЕС, формированию новых механизмов диалога между наднациональными институтами, странами-членами и региональными властями. В то же время концепцию «территориального сплочения» можно признать новацией либо малоудачной, либо, по крайне мере, требующей конкретизации и обкатки на практике в условиях бескризисного, «спокойного» социально-экономического и политического развития.

\section{ЛИТЕРАТУРА}

1. Keating M. A Quarter Century of the Europe of the Regions // Regional and Federal Studies. 2008. № 5. P. $629-635$.

2. Ruge U. Die Erfindung des “Europa der Regionenn”. Kritische Ideengeschichte eines konservativen Konzepts. Frankfurt/Main, 2003.

3. Cohesion Policy and European Integration: Building Multi-Level Governance / ed. by L. Hooghe. Oxford, 1996.

4. Multilevel Governance in Theory and Practice / ed. by I. Bache, M. Flinders. Oxford, 2004.

5. Panara C., De Becker A. The Role of the Regions in the European Union: The "Regional Blindness" of Both the EU and the Member States // The Role of the Regions in EU Governance. Berlin, Heidelberg, 2011. P. 297-346.

6. Бусыгина И.М. Политическая регионалистика. М., 2006.

7. Яровой Г.О. Регионализм и трансграничное сотрудничество в Европе. СПб., 2007.

8. Consolidated Version of the Treaty Establishing the European Community. URL: http://eur-lex.europa.eu/legalcontent/EN/TXT/PDF/?uri=CELEX:12002E/TXT\&from=EN.

9. Consolidated Version of the Treaty on the Functioning of the European Union. URL: http://eurlex.europa.eu/LexUriServ/LexUriServ.do?uri=OJ:C:2010:083:FULL:EN:PDF.

10. European Commission. Investing in Europe's Future. Fifth Report on Economic, Social and Territorial Cohesion. URL: http://ec.europa.eu/regional_policy/sources/docoffic/official/reports/cohesion5/pdf/5cr_part1_en.pdf.

11. European Commission. Green Paper on Territorial Cohesion, the Way http://ec.europa.eu/regional_policy/sources/docgener/panorama/pdf/mag28/mag28_en.pdf.

12. Territorial Agenda of the European Union 2020. Towards an Inclusive, Smart and Sustainable Europe of Diverse Regions. URL: http://www.mmr.cz/getmedia/fb9825b3-9d22-490d-bcd0-43528e505ea3/Uzemni-agenda-2020-28-(EN-verze).

13. Boehme K., Holstein F., Toptsidou M. Report on the Assessment of Territorial Cohesion and the Territorial Agenda 2020 of the European Union. URL: http://regionalispolitika.kormany.hu/download/c/47/31000/1_Spatial_Foresight_Report_on_the_Assessment_of_Territorial_Cohesion_and_the_TA2020_lr.pdf.

14. Arribas G.V., Hoegenauer A.-L. Legislative Regions after Lisbon: A New Role for Regional Assemblies? // The Palgrave Handbook of National Parliaments and the European Union. N.Y., 2015. P. 133-148.

15. European Parliament. The Principle of Subsidiarity. URL: http://www.europarl.europa.eu/ftu/pdf/en/FTU 1.2.2.pdf.

16. Committee of the Regions. In Preparation for the Copenhagen European Council. URL: http://eur-lex.europa.eu/legalcontent/EN/TXT/?uri=uriserv:OJ.C .2003.073.01.0043.01.ENG\&toc=OJ:C:2003:073:TOC.

17. Bourne A. Europe, Constitutional Debates and the Spanish State of Autonomies // Perspectives on European Politics and Society. 2009. № 3. P. 283300 .

Troitskiy Evgeny F. Tomsk State University (Tomsk, Russia). E-mail: eft@rambler.ru

THE LISBON TREATY AND THE REGIONAL DIMENSION OF THE EUROPEAN UNION.

Keywords: Lisbon Treaty; territorial cohesion; subsidiarity; early warning system.

The Lisbon Treaty which entered into force on December 1, 2009 introduced into the EU law a number of novelties aimed at strengthening the regional dimension of EU's functioning. This paper aims at both giving a comprehensive analysis of changes introduced by the Lisbon Treaty in the functioning of the link between the EU and its regions and matching the "letter" of the Treaty with post-Lisbon political realities. Its primary sources are the text of the Treaty, reports of the European Parliament, European Commission and the Committee of the Regions on the problems of economic, social and territorial cohesion and multi-level governance, and independent expert evaluations. First and foremost, the Lisbon Treaty has reflected a new approach to the EU's cohesion policy. The very notion of cohesion was expanded: the earlier concept of "economic and social cohesion" was replaced with the "economic, social and territorial cohesion". The categories of regions in need of support were defined more precisely. But the formula of "territorial cohesion" requires decoding which the Treaty does not provide. The objectives set under the umbrella concept of "territorial cohesion" turned out to be largely declarative and devoid of concrete indicators allowing for the appraisal of progress. The Lisbon Treaty has introduced a number of provisions opening new opportunities for regions' taking part in EU decision-making and defending their interests. The principle of subsidiarity was extended to cover the regional and local levels. The principle of regional and local autonomy was enshrined in the Treaty. The Treaty has strengthened the role of national parliaments in the EU legislative process. They received the right to monitor the application of the principle of subsidiarity through a new "early warning system". In the countries where upper chambers of parliaments 
represent federation members or territorial units the "early warning system" opens for the regions a direct opportunity to influence the EU legislative process. The Lisbon Treaty expanded the competences of the Committee of the Regions that for the first time received the right to appeal to the Court of Justice. The author concludes that the novelties introduced by the Lisbon Treaty into the sphere of regional involvement in EU policies are modest if compared with the projects that the Committee of the Regions and "strong" regions had put forward when the Treaty was under preparation. However, these novelties can hardly be dismissed as insignificant. In the long term they are likely to bring about the consolidation of the regional dimension of EU's political space through a stronger role of the Committee of the Regions, intensified interactions between national parliaments and EU institutions and the development of new mechanisms of dialogue between supranational institutions, member states and regional authorities.

\section{REFERENCES}

1. Keating, M. (2008) A Quarter Century of the Europe of the Regions. Regional and Federal Studies. 5. pp. 629-635. DOI: $10.1080 / 13597560802351630$

2. Ruge, U. (2003) Die Erfindung des "Europa der Regionenn". Kritische Ideengeschichte eines konservativen Konzepts [The invention of "Europe of the Region". Critical ideas of a conservative concept]. Frankfurt/Main: Campus Verlag.

3. Hooghe, L. (ed.) (1996) Cohesion Policy and European Integration: Building Multi-Level Governance. Oxford: Clarendon Press.

4. Bache, I. \& Flinders, M. (eds) (2004) Multilevel Governance in Theory and Practice. Oxford: Oxford Scholarship Online. DOI: 10.1093/0199259259.001.0001/.

5. Panara, C. \& De Becker, A. (2011) The Role of the Regions in the European Union: The "Regional Blindness" of Both the EU and the Member States. In: Panara, C. \& De Becker, A. (eds) The Role of the Regions in EU Governance. Berlin, Heidelberg: Springer-Verlag. pp. 297-346.

6. Busygina, I.M. (2006) Politicheskaya regionalistika [Political regionalism]. Moscow: ROSSPEN.

7. Yarovoy, G.O. (2007) Regionalizm i transgranichnoe sotrudnichestvo v Evrope [Regionalism and cross-border cooperation in Europe]. St. Petersburg: Norma.

8. European Union. (2002) Consolidated Version of the Treaty Establishing the European Community. [Online] Available from: http://eurlex.europa.eu/legal-content/EN/TXT/PDF/?uri=CELEX:12002E/TXT\&from=EN.

9. European Union. (2002) Consolidated Version of the Treaty on the Functioning of the European Union. [Online] Available from: http://eurlex.europa.eu/LexUriServ/LexUriServ.do?uri=OJ:C:2010:083:FULL:EN:PDF.

10. Breska, von E. (ed.) Investing in Europe's Future. Fifth Report on Economic, Social and Territorial Cohesion. [Online] Available from: http://ec.europa.eu/regional_policy/sources/docoffic/official/reports/cohesion5/pdf/5cr_part1_en.pdf.

11. European Commission. (2008) Green Paper on Territorial Cohesion, the Way Ahead. [Online] Available from: http://ec.europa.eu/regional_policy/sources/docgener/panorama/pdf/mag28/mag28_en.pdf.

12. European Union. (n.d.) Territorial Agenda of the European Union 2020. Towards an Inclusive, Smart and Sustainable Europe of Diverse Regions. [Online] Available from: http://www.mmr.cz/getmedia/fb9825b3-9d22-490d-bcd0-43528e505ea3/Uzemni-agenda-2020-28-(EN-verze).

13. Boehme, K., Holstein, F. \& Toptsidou, M. (2015) Report on the Assessment of Territorial Cohesion and the Territorial Agenda 2020 of the European Union.
http://regionalispolitika.kormany.hu/download/c/47/31000/1_Spatial_Foresight_Report_on_the_Assessment_of_Territorial_Cohesion_and_the_TA2 020_lr.pdf.

14. Arribas, G.V. \& Hoegenauer, A.-L. (2015) Legislative Regions after Lisbon: A New Role for Regional Assemblies? In: Neuhold, C., Rozenberg, O., Smith, J. \& Hefftler, C. (eds) The Palgrave Handbook of National Parliaments and the European Union. New York: Palgrave Macmillan UK. pp. 133-148.

15. European Parliament. The Principle of Subsidiarity. [Online] Available from: http://www.europarl.europa.eu/ftu/pdf/en/FTU_1.2.2.pdf.

16. Committee of the Regions. In Preparation for the Copenhagen European Council. [Online] Available from: http://eur-lex.europa.eu/legalcontent/EN/TXT/?uri=uriserv:OJ.C_.2003.073.01.0043.01.ENG\&toc=OJ:C:2003:073:TOC.

17. Bourne, A. (2009) Europe, Constitutional Debates and the Spanish State of Autonomies. Perspectives on European Politics and Society. 3. pp. 283300. DOI: $10.1080 / 15705850802223424$ 